\title{
Life Cycle Assessment of North American Laminated Strand Lumber (LSL) Production
}

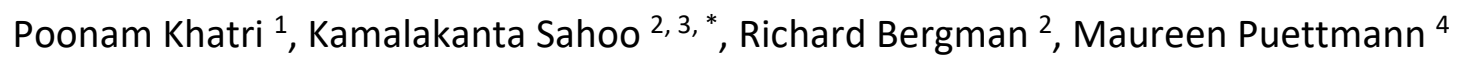

1. Department of Chemical Engineering, Institute of Chemical Technology, Mumbai, 400019, India; E-Mail: poonam khatri@hotmail.com

2. Forest Products Laboratory, United States Forest Service, Madison, WI 53726, United States; EMails: kamalakanta.sahoo@usda.gov; richard.d.bergman@usda.gov

3. Biological Systems Engineering, University of Wisconsin-Madison, Madison, WI 53706, United States

4. WoodLife Environmental Consultants \& Consortium for Research on Renewable Industrial Materials (CORRIM), United States; E-Mail: maureen.puettmann@woodlifeconsulting.com

* Correspondence: Kamalakanta Sahoo; E-Mail: kamalakanta.sahoo@usda.gov

Academic Editor: Jorge de Brito

Special Issue: $\underline{\text { New Trends on Circular Economy Building and Construction Materials }}$

Recent Progress in Materials

2021, volume 3, issue 4

doi:10.21926/rpm.2104048
Received: June 18, 2021

Accepted: December 08, 2021

Published: December 15, 2021

\begin{abstract}
Raw materials for buildings and construction account for more than $35 \%$ of global primary energy use and nearly $40 \%$ of energy-related $\mathrm{CO}_{2}$ emissions. The Intergovernmental Panel on Climate Change (IPCC) emphasized the drastic reduction in GHG emissions and thus, wood products with very low or negative carbon footprint materials can play an important role. In this study, a cradle-to-grave life cycle assessment (LCA) approach was followed to quantify the environmental impacts of laminated strand lumber (LSL). The inventory data represented North American LSL production in terms of input materials, including wood and resin, electricity and fuel use, and production facility emissions for the 2019 production year. The contribution of cradle-to-gate life cycle stages was substantial $(>70 \%)$ towards the total (cradle-to-grave) environmental impacts of LSL. The cradle-to-gate LCA results per $\mathrm{m}^{3} \mathrm{LSL}$
\end{abstract}

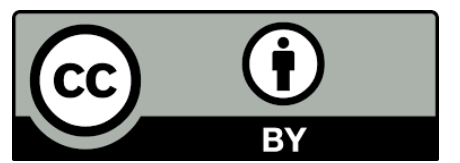

(c) 2021 by the author. This is an open access article distributed under the conditions of the Creative Commons by Attribution License, which permits unrestricted use, distribution, and reproduction in any medium or format, provided the original work is correctly cited. 
were estimated to be $275 \mathrm{~kg} \mathrm{CO}_{2}$ eq global warming, $39.5 \mathrm{~kg} \mathrm{O}_{3}$ eq smog formation, $1.7 \mathrm{~kg} \mathrm{SO}$ eq acidification, $0.2 \mathrm{~kg} \mathrm{~N}$ eq eutrophication, and $598 \mathrm{MJ}$ fossil fuel depletion. Resin production as a part of resource extraction contributed $124 \mathrm{~kg} \mathrm{CO} 2$ eq (45\%). The most relevant unit processes in their decreasing contribution to their cradle-to-grave GW impacts were resource extraction, end-of-life (EoL), transportation (resources and product), and LSL manufacturing. Results of sensitivity analysis showed that the use of adhesive, consumption of electricity, and transport distance had the greatest influences on the LCA results. Considering the whole life cycle of the $L S L$, the final product stored $1,010 \mathrm{~kg} \mathrm{CO}{ }_{2} \mathrm{eq} / \mathrm{m}^{3}$ of $\mathrm{LSL}$, roughly two times more greenhouse gas emissions over than what was released $\left(493 \mathrm{~kg} \mathrm{CO} 2 \mathrm{eq} / \mathrm{m}^{3}\right.$ of $\mathrm{LSL}$ ) from cradleto-grave. Overall, LSL has a negative GW impact and acts as a carbon sink if used in the construction sector. The study results are intended to be important for future studies, including waste disposal and recycling strategies to optimize environmental trade-offs.

\section{Keywords}

Engineered wood products; green buildings; laminated strand lumber; environmental impacts; life cycle assessment; environment product declarations

\section{Introduction}

The world is facing severe challenges from climate change and resource scarcity due to exponential growth in population and their rising standard of living [1]. Raw materials for buildings and construction account for more than $35 \%$ of global primary energy use and nearly $40 \%$ of energyrelated $\mathrm{CO}_{2}$ emissions [2]. Wood has been an important renewable resource catering to the needs of human civilization in different forms. The consumption of renewable energy in the year 2020 has reached a record share of $12 \%$ in total energy consumption in the U.S, and $20 \%$ of this consumption was from wood and waste energy [3]. The Intergovernmental Panel on Climate Change (IPCC) emphasized the need for a drastic reduction in GHG emissions. Thus, wood products with low or negative carbon footprint materials can play an important role. The use of wood-based products in the construction sector is a significant source of environmental improvement and economic gain [4, 5]. The environmental impacts of wood products have been estimated to be lesser than conventional equivalents in the construction sector $[5,6]$. In response to the increasing demands for sustainable buildings, the construction sector has guided the quest for many functional innovations in wood-based products [7]. These innovations have centered on an overarching plan of using the forest resources to their maximum potential to produce low-carbon-footprint construction products. For buildings, the carbon stored in wood products remains fixed for a very long time [8]. A global market for a wide group of engineered wood products (EWPs) has emerged in the past several decades to better utilize the available wood source, including mill residues and small-diameter trees. They are so named because they are engineered to exhibit desirable mechanical and physical properties while efficiently using wood. Resource efficiency for EWPs is based partially on adhesive bonding technology applied to different elements produced as coproducts (wood chips, strands, flakes) in primary wood processing [9]. EWPs can form larger and complex structural sections, reducing the natural flaws along with enhancing dimensional strength 
and homogenous traits [10]. One category of such products is structured composite lumber (SCL) made from wood strands of different tree species and commonly used in structural applications [11]. SCLs include laminated veneer lumber, laminated strand lumber, oriented strand lumber, and parallel strand lumber.

Laminated strand lumber (LSL) is an important member of the family of SCL [12]. They are made of wood strands pressed together and bonded with adhesive into billets (large, densified mats) which are then cut into different sizes. The largest industrial production of LSL occurs in North America (333,780 $\mathrm{m}^{3}$ in the year 2019); two total manufacturers, one in the U.S. and the other in Canada [13]. LSL is produced from small-diameter trees (with a high length to thickness ratio), which are unsuitable for solid wood building materials like framing lumber [14]. The most used wood species for LSL production in North America are a mixture of aspen (Populus tremuloides), yellow birch (Betula alleghaniensis), and silver (soft: Acer saccharinum), and sugar maple (hard: Acer saccharum).

The uniform engineered properties of LSL have been useful in various applications, such as frames, studs, headers, and beams. The production and use of LSL and SCL, in general, have progressively increased mainly because of the low energy inputs and emissions when compared to other non-wood construction materials $[9,15,16]$. Moreover, considering that carbon sequestered through the forests and carbon dioxide emissions saved from avoiding using other construction materials (steel and concrete) would make them suitable for alleviating impacts from climate change $[10,17,18]$. The use of wood products in the construction sector has estimated a sink of 441 million tonnes $\mathrm{CO}_{2}$ eq./year in 2030 [6]. Up to $14-34 \% \mathrm{CO}_{2}$ emissions and $12-19 \%$ fossil fuel usage would be avoided by efficient use of sustainably grown forest resources [4].

Along with the increasing interest in using EWPs (LSL in this study) in construction, interest in assessing their sustainability has also increased. Tools like life cycle assessment (LCA) have attained high popularity for assessing the environmental impacts of wood products [19]. LCA-based information is integral to decision-making and continuous improvement in the existing products over time [20]. The findings of LCA studies in the construction sector have become increasingly important in obtaining green building certifications, environmental product declarations (EPDs), and informing the public and policymakers [16, 20, 21]. Because of the advent of Environmental Preferential Purchasing (EPP), documenting the environmental performance of building products using tools like LCA has become a widespread emergent global trend [5, 22]. In general, the manufacturing of SCL has some process inputs in the form of energy and chemicals (e.g., resins) that tend to have toxicological impacts. The fossil energy used in the production of adhesives is considered high compared to the other inputs [23]. Also, the volatile organic compounds (VOCs) in the adhesive formulations can pose environmental concerns. Therefore, it becomes imperative to understand the environmental impacts involved in the production, use, and different disposal options of LSL.

The objective of this study was to perform the LCA and quantify the cradle-to-grave (cradle-togate and gate-to-grave) environmental impacts of LSL. This study was the first to address gate-tograve stages as part of a full cradle-to-grave environmental assessment of LSL. We also analyzed the three end-of-life (EoL) options of LSL, such as (i) landfilling (with methane capture) of LSL (base case), (ii) burning of LSL to capture heat, and (iii) recovering LSL for reuse. It is intended to be useful for future studies in the area of wood LCAs involving waste disposal and recycling strategies to optimize environmental trade-offs. 


\section{Methodology}

\subsection{Goal and Scope Definition}

This LCA study followed the ISO 14040 and 14044 standards [24, 25], and Underwriters Laboratories Environment (ULE) product category rules (PCR) for North American Structural and Architectural Wood Products [26, 27]. The goal of the study was to quantify the cradle-to-grave environmental impacts of LSL in North America. The scope of this LCA study included all lifecycle stages of LSL, starting from resources management activities through end-of-life. Along with the environmental impacts, additional indicators such as energy use, waste generation, and many more $[26,27]$ indicators were also estimated in this study. The primary audience for the LCA study includes the LSL manufacturers, the American Wood Council, Canadian Wood Council, building developers and owners, architects, and other LCA practitioners.

\subsection{Functional or Declared Unit}

The role of the functional or declared unit in an LCA study is to give a reference against which all environmental inputs and outputs required to perform the functions of the LSL production system can be delineated. For the cradle-to-grave study, we used a functional unit of $1-\mathrm{m}^{3}$ of LSL used as the framing and disposed of at EoL.

\subsection{Allocation}

Products and multiple co-products are common in wood-based manufacturing systems. Consequently, an LCA study needs to select an allocation method for assigning environmental impacts on each product. The wood products PCR requires using a mass allocation approach [27]. All inputs and direct emissions were allocated to various outputs (i.e., LSL and its co-products) based on their respective oven-dry (OD) mass.

\subsection{System Boundary}

This study considered a cradle-to-grave (cradle-to-gate and gate-to-grave) system boundary (Figure 1). The cradle-to-gate system boundary of LSL begins with resource extraction and ends with LSL packaged to leave the mill gate (Figure 1). The key process included resource extraction (A1), transportation (A2), and product manufacturing (A3). Cradle-to-gate methylene diphenyl diisocyanate $(\mathrm{MDI})$ resin production was part of $A 1$. The gate-to-grave system consists of product transportation (A4), product installation (A5), product use (B1), building demolition (C1), and the EoL stage. Three disposal options considered for handling LSL after the building reached EoL were: i) landfill disposal with methane capture (baseline), ii) burning the LSL waste to produce heat and assessing its energy substitution benefits, iii) recovering LSL for reuse for a second functional life. The base case EoL considered the transport of (LSL) waste to a disposal site (C2) and disposal of waste (C4). The EoL options are discussed in detail in section 2.8.3. In this case, co-products produced during the LSL manufacturing process were partially burned onsite to generate heat for internal processes. The co-products were not tracked once they left the system boundary. This study included all materials and energy flows in the analysis. Hence, there were no cut-offs used in the impact assessment $[20,27]$. 


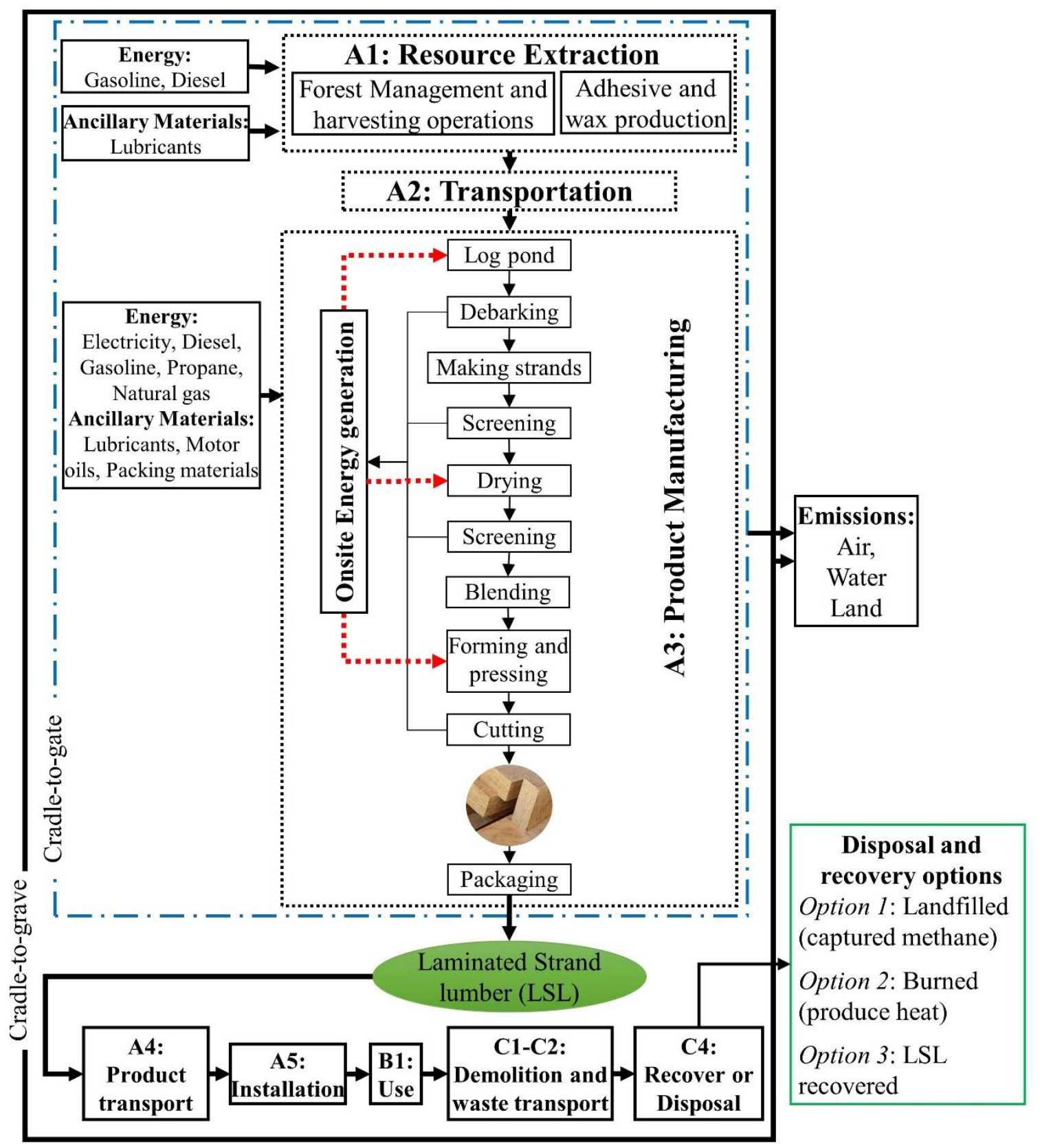

Figure 1 Cradle-to-grave system boundary for laminated strand lumber (LSL) system.

\subsection{Description of LSL Life Cycle Processes}

\subsubsection{Resource Extraction (A1)}

Whole hardwood logs were used to manufacture LSL in North America. The production of the logs began in the forest and included the forestry activities that are customary to central Canada [28] and the northeast-north central (NE-NC) region of the US [29]. Post-harvest and stand establishment activities such as site preparation and planting scenarios vary substantially with the owner of the timberland and region. The hardwood forest for these two regions did not include slash reduction activities and assumed natural forest regeneration [29]. The harvest included felling, skidding, processing, and loading for both commercial thinning and final harvest operations. The weighted average allocation to different processes considers inherent differences in site 
productivity and energy usage by different kinds of logging equipment. Table 1 shows the contribution of the different regions supplying hardwood logs to produce LSL in North America. The weighted average density of incoming logs was $385 \mathrm{OD} \mathrm{kg} / \mathrm{m}^{3}$, far less than the final product which has an expected range of 625 to $690 \mathrm{~kg} / \mathrm{m}^{3}$ depending on the grade of the LSL produced [12]. This difference is from the substantial pressing of the mat into the billet. This stage also included the production of secondary materials such as adhesive and wax used in LSL manufacturing.

Table 1 Wood feedstock types and sources for laminated strand lumber (LSL) production, $1 \mathrm{~m}^{3}$ (unallocated).

\begin{tabular}{lll}
\hline Feedstocks by regions & OD kg/ $\mathbf{~ m}^{\mathbf{3}}$ of LSL & $\begin{array}{c}\% \\
\text { Contribution }\end{array}$ \\
\hline Hardwood, logs, US Northeast & 894.62 & 24.8 \\
Hardwood, logs, Canada & 977.21 & 75.2 \\
TOTAL North American (weighted average) & 956.76 & 100 \\
\hline
\end{tabular}

${ }^{1}$ The value of 956.79 oven-dry (OD) $\mathrm{kg}$ of hardwood log corresponds to $2.48 \mathrm{~m}^{3}$

\subsubsection{Transportation (A2)}

Forest resources, i.e., logs, were transported by trucks and rail from the forest to the mill. Resins and various ancillary materials and additives are used in LSL production. These materials were also transported in trucks and rail. Table 2 shows the weighted average haul distance for feedstocks and other materials used in LSL manufacturing. Most log transports were conducted by logging trucks, not rail, so its weighted distance was higher.

Table 2 Weighted average delivery distance (one-way) for materials to the laminated strand lumber mills.

\begin{tabular}{|c|c|c|c|}
\hline Input material & $\begin{array}{l}\text { Mode of } \\
\text { transport }\end{array}$ & $\begin{array}{l}\text { Weighted transport } \\
\text { distance }(\mathrm{km})\end{array}$ & $\begin{array}{l}\text { Weighted coefficient of } \\
\text { variation (\%) }\end{array}$ \\
\hline \multicolumn{4}{|l|}{ Feedstocks } \\
\hline \multirow{2}{*}{ Hardwood, logs } & Truck & 204.16 & 51.4 \\
\hline & Rail & 41.09 & 246.5 \\
\hline \multicolumn{4}{|l|}{$\begin{array}{l}\text { Non-feedstocks } \\
\text { materials }\end{array}$} \\
\hline Resins and waxes & Rail & 2170.19 & 50.6 \\
\hline \multirow{2}{*}{ Ancillary material } & Truck & 1015.94 & 73.2 \\
\hline & Rail & 157.19 & 246.5 \\
\hline Other materials & Truck & 824.20 & 27.7 \\
\hline
\end{tabular}

2.5.3 LSL Manufacturing (A3) 
The LSL manufacturing process is an automated, process-controlled, and linear process as illustrated in Figure 2. Once the logs reached the mill, they were debarked after softening in a heated log pond and then run through rotating knives of a stranding machine to produce strands. Strands were screened, dried, and then screened again for the bonding process. The waterproof adhesive, $\mathrm{MDI}$, was sprayed on the strands (for strong bonding between strands) moving through a rotating drum. The strand mat was cured using steam and pressure, and then the LSL billets were cut to size and received a protective end [edge] seal before packaging and shipping. The weighted density of LSL was estimated at $647.2 \mathrm{OD} \mathrm{kg} / \mathrm{m}^{3}$ [including additives]. Although this density was much higher than the incoming logs, it is consistent with the values reported by other studies [12, 30, 31]. A brief description of the unit processes is presented next.

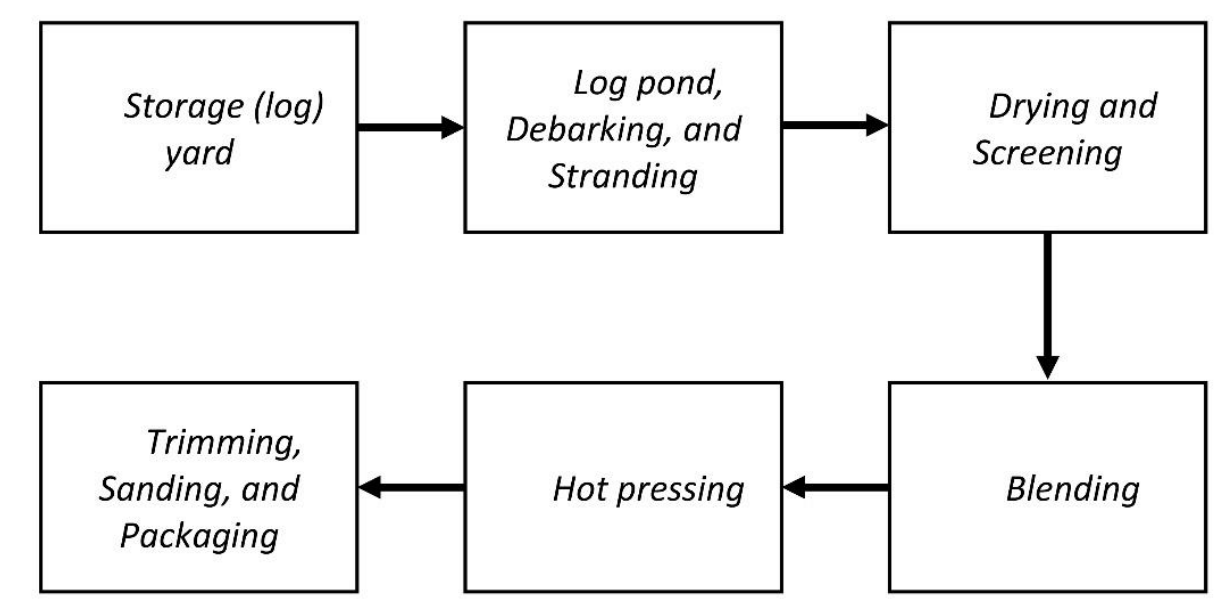

Figure 2 Flow diagram of laminated strand lumber manufacturing processes (adapted from Craig and Abdullahi [12]).

Storage Yard. Freshly cut logs were received at the mill in tree length or shorter bolts varying from 2.5-2.6 meters (8.2-8.5 feet). In a "first-in, first-out" manner, logs were unloaded and stacked in the yard. The storage yard acts as a supply stock for the mill operations. Weight and moisture levels of all logs were determined. Log stackers or front-end loaders moved logs from the storage yard to the log pond. The inputs for storage yard operations were logs, electricity, fuel, and lubricants. Outputs were logs moved to log ponds.

Log Pond, Debarking, and Stranding. The logs were transported and placed in hot ponds where the wood temperature was raised to $20^{\circ} \mathrm{C}$ before debarking. Here, the logs were debarked using ring or drum debarkers. The bark was either used as a fuel within the mills or sold as a co-product. The debarked logs were stranded, reducing them to thin strands of 0.76-1.3 mm thick, 300-330 mm long, and 19-38 $\mathrm{mm}$ wide. Mills use disc screens to remove the unacceptable strands, either used as fuel in the mill or sold as co-products. The acceptable strands were sent to the green bins [32].

Drying and Screening. Strands stored in the green bins were fed to the rotary drum dryers to reduce their moisture content to less than $2-3 \%$ from a range of $50 \%$ to over $100 \%$ on a dry basis [33]. The emissions from the drying step include water vapors, small wood particles, and VOCs. The inlet temperature of the dryer can vary between $300-500^{\circ} \mathrm{C}$. Hot air was passed through the strands until the desired moisture level was achieved, usually 20-25 minutes [32]. Dried strands were stored 
in a dry storage bin where they were further screened to sort by size and then stored in separate bins [32].

Blending. In the blending step, the dried acceptable strands were blended with additives. The additives, adhesive and wax, were applied to the surface of strands in rotary drum blenders [32]. In addition, an emulsified wax was applied using spray nozzles. The adhesive used was MDI, which is on the US Environmental Agency (EPA) Toxics Release Inventory [34]. Zinc borate was also blended with the strands to prevent fungal decay and provide termite resistance. Based on the OD weight of LSL, adhesive and wax content usually ranges between $3-4 \%$ and less than $1 \%$, respectively. The resultant mix from the blenders was sent to forming bins.

Forming. The blended furnish was fed onto conveyors into forming bins. These conveyors pass through the forming bin consistently to ensure uniform mass distribution. From the forming bins, the strands were fed onto "orienteers" to position all the strands in the long direction of the final product. After forming the mat, a release agent was sprayed on the mat surfaces to prevent it from clinging to the press platens [32].

Hot Pressing. A steam-injection press was used in LSL manufacturing. The purpose was to cure the additives [32]. The temperature in the press was maintained between $375^{\circ} \mathrm{C}$ and $410^{\circ} \mathrm{C}$ with a circulation of hot oil through a labyrinth made inside the platen. A separate labyrinth of channels built in the platens allows steam circulation. The cycle time for manufacturing LSL billet of thickness over $75 \mathrm{~mm}$ would be extremely high if hot pressing occurs without steam injection [32]. After the additives were fully cured, the LSL billets were removed from the press for cooling.

Trimming, Sanding, and Packaging. The cooled LSL billets were stacked for finishing, which depends on the requirements of customers. Finishing may require a simple trimming of the edges and ends, strapping, and shipping. Some LSL products require sanding (one or both sides), cutting to standard dimensions or sizes requested by the customer. Trimmings and dust from sanding were used as fuel but could be sold as a by-product. The discarded LSL billets were sold at a discounted price or simply used as fuel. The final LSL product was stacked and packaged for delivery to the customers. The LSL packaging materials included wooden spacers, plastic wrap, and cardboard (Table 3). Wooden spacers constituted the largest part of LSL packaging.

Table 3 Materials used in packaging and shipping $1.0 \mathrm{~m}^{3} \mathrm{LSL}$, North American average (unallocated).

\begin{tabular}{lll}
\hline Material & Value (kg) & Weighted coefficient of variation (\%) \\
\cline { 2 - 3 } Plastic strapping & 0.045 & 228.0 \\
Plastic packaging (bags) & 0.004 & 246.5 \\
Plastic Packaging (wrap) & 0.049 & 246.5 \\
Wooden spacers & 0.433 & 246.5 \\
Cardboard spacers & 0.114 & 81.1 \\
Total & 0.532 & \\
\hline
\end{tabular}




\subsection{Data Collection Method}

For LSL, the life cycle inventory ( $\mathrm{LCl}$ ) data were obtained by surveying the two producers in North America for the year 2019. The survey used can be found as an appendix of Sahoo et al. [35]. Material and energy balances were calculated by a spreadsheet algorithm using data from primary and secondary data sources. From weight-averaging these material and energy values, environmental impacts were estimated by modeling emissions through SimaPro 9.1 software [36]. The primary data obtained from the surveys were weight-averaged using the formula shown in equation 1.

$$
\bar{P}_{w}=\frac{\sum_{i=1}^{N} P_{i} x_{i}}{\sum_{i=1}^{N} x_{i}}
$$

Where $\bar{P}_{w}$ the weighted average of the values reported by the "N" mills, $P_{i}$ was the reported "i" mill's value such as production, and $x_{i}$ is the fraction of the mill's value to the combined total production of all the surveyed mills. Because the surveyed mill's data varied between facilities, a statistical analysis was conducted. In this study, the weighted coefficient of variation was calculated [37]. The weighted coefficient of variation $\left(\mathrm{CoV}_{w}\right)$ is the weighted standard deviation $\left(s d_{w}\right)$ divided by the weighted mean $\bar{P}_{w}$ as shown in equation 2 .

$$
\mathrm{CoV}_{w}=\frac{\sqrt{\left(\sum_{i=1}^{N} w_{i} \times\left(x_{i}-\bar{x}_{w}\right)^{2}\right) /\left[\left(\left(N^{\prime}-1\right) \sum_{i=1}^{N} w_{i}\right) / N^{\prime}\right]}}{\bar{P}_{w}}
$$

Where, $w_{i}$ is the weight of the $i$ th observation,' $N^{\prime \prime}$ is the number of nonzero weights, and $\bar{x}_{w}$ is the weighted mean of the observations $(N)$. Whenever missing data occurred for survey items, they were checked with facility personnel to determine whether it was an unknown value or zero. Missing data were carefully noted, so they were not averaged as zeros. Any outliers were resolved by contacting mill personnel. The data from the surveys were assimilated and converted to a unit production basis of volume in the $\mathrm{SI}$ unit of $\mathrm{m}^{3}$ that represents a composite of the North American mills surveyed but may not represent any specific mill. The secondary data on transport, electrical grid inputs, fuels, and forest resource activities were obtained from DATASMART [38] which represents the North America region data, and Ecoinvent 3.6 (Ecoinvent, Zurich, Switzerland). The previous LCA study on LSL production [32] and other sources [39] were used to supplement the emissions data which were not provided by the mills. The secondary data on forest management and harvesting used in this study was modified from earlier studies to reflect species management [29]. Primary data were not collected for inputs, including forest resources and adhesive and wax production.

\subsection{Gate-to-Gate Lifecycle Inventory}

Table 4 represents LSL production's gate-to-gate inputs (materials, transport, fuels, and energy) and outputs (main products, co-products, emissions, and waste). These data were linked to the upstream unit processes for forest resources, ancillary materials, transportation, fuels, and electricity to calculate cradle-to-gate environmental impacts for LSL. 
Table 4 Environmental inputs and outputs to produce $1 \mathrm{~m}^{3}$ of laminated strand lumber, North American (unallocated, gate-to-gate, weight-averaged).

\begin{tabular}{|c|c|c|c|}
\hline Description & Value & Outputs & Value \\
\hline Products, co-products (OD kg) & & Emissions to air $(\mathrm{kg})$ & \\
\hline Laminated Strand Lumber & $647.21(65.33 \%)$ & Acetaldehyde ${ }^{a}$ & 3.10E-03 \\
\hline Strands & 32.59 (3.29\%) & Acrolein ${ }^{a}$ & 7.07E-04 \\
\hline Log yard/pond debris & $22.49(2.27 \%)$ & Benzene $^{b}$ & 4.47E-05 \\
\hline Hog fuel & $43.92(4.43 \%)$ & Carbon monoxide ${ }^{a}$ & 6.90E-02 \\
\hline Bark & 210.7 (21.27\%) & Carbon dioxide, biogenic $^{b}$ & $4.66 \mathrm{E}+02$ \\
\hline Short stands & $7.43(0.75 \%)$ & Dust (wood) ${ }^{\mathrm{b}}$ & $1.49 \mathrm{E}-01$ \\
\hline Wood residues & $9.46(0.95 \%)$ & Formaldehyde ${ }^{a}$ & $2.72 \mathrm{E}-03$ \\
\hline Other wood residues & $16.92(1.71 \%)$ & Hydrogen chloride ${ }^{b}$ & 3.10E-04 \\
\hline Resource inputs & & Lead $^{\mathrm{a}}$ & 8.15E-06 \\
\hline Roundwood logs & $2.48 \mathrm{~m}^{3}$ & Mercury ${ }^{a}$ & $1.21 \mathrm{E}-06$ \\
\hline Wax & $0.61 \mathrm{~kg}$ & Methane ${ }^{b}$ & 3.00E-04 \\
\hline Adhesive -MDI & $30.82 \mathrm{~kg}$ & Methane, Biogenic ${ }^{b}$ & $5.90 \mathrm{E}-03$ \\
\hline Zinc Borate & $0.26 \mathrm{~kg}$ & Methanol $^{b}$ & 2.10E-03 \\
\hline Emulsified wax & $2.27 \mathrm{~kg}$ & Methylene diisocyanate ${ }^{b}$ & 4.30E-03 \\
\hline Water, municipal & $205.43 \mathrm{~L}$ & Nitroux oxide $\left(\mathrm{NO}_{\mathrm{x}}\right)^{\mathrm{b}}$ & $2.91 \mathrm{E}-01$ \\
\hline Fuel and energy inputs & & Dintrogen monoxide $\left(\mathrm{N}_{2} \mathrm{O}\right)^{\mathrm{b}}$ & 7.09E-02 \\
\hline Electricity, at grid & 276.01 kWh & $\mathrm{PM}_{2.5}$ & $3.68 \mathrm{E}-02$ \\
\hline Wood fuel & 264.56 OD kg & Particulates, PM10-PM2.5 & $9.23 \mathrm{E}-02$ \\
\hline Propane & $9.78 \mathrm{~L}$ & $\mathrm{PM} 10^{\mathrm{a}}$ & $1.65 \mathrm{E}-01$ \\
\hline Natural gas & $0.4 \mathrm{~m}^{3}$ & Particulates, unspecified ${ }^{a}$ & $2.74 \mathrm{E}-02$ \\
\hline Diesel & $2.48 \mathrm{~L}$ & Phenol $^{\mathrm{b}}$ & 3.30E-03 \\
\hline Gasoline & $0.01 \mathrm{~L}$ & Propanal ${ }^{b}$ & 2.70E-03 \\
\hline Ancillary materials inputs & & Sulfur dioxide ${ }^{a}$ & $3.95 \mathrm{E}-02$ \\
\hline Sealant & $0.38 \mathrm{~kg}$ & VOC $^{a}$ & $3.65 \mathrm{E}-01$ \\
\hline Release agent & $1.04 \mathrm{~kg}$ & Wastes to treatment $(\mathrm{kg})$ & \\
\hline Motor oil & $0.02 \mathrm{~kg}$ & Wood waste & 0.239 \\
\hline Greases & $0.01 \mathrm{~kg}$ & Boiler ash & 7.995 \\
\hline Hydraulic fluid & $0.19 \mathrm{~kg}$ & Recycled metals & 0.471 \\
\hline Antifreeze & $0.13 \mathrm{~L}$ & Plastic strapping & 0.006 \\
\hline Lubricating fluid & $0.07 \mathrm{~kg}$ & Cardboard & 0.023 \\
\hline Transportation & & Paper & 0.002 \\
\hline Wood feedstock & $638.97 \mathrm{tkm}$ & Batteries & 0.0001 \\
\hline Resins and wax & $133.75 \mathrm{tkm}$ & & \\
\hline Ancillary material & 11.19 tkm & & \\
\hline
\end{tabular}

${ }^{\mathrm{a}}$ Emissions data are from survey data; ${ }^{\mathrm{b}}$ Emissions data are estimated from US Environmental Protection Agency's air emissions factors for engineered wood products manufacturing [39], or previous study [32], or literature [40] 
The values in parenthesis of the inputs in Table 4 indicate their percent allocation applied in the LCA. According to the weighted average approach, $1 \mathrm{~m}^{3} \mathrm{LSL}$ (647.21 OD kg) production required $2.48 \mathrm{~m}^{3}$ (956.76 OD kg) wood feedstock. Most of the energy required in LSL manufacturing came from mill residues (bark, hogged fuel) used in boilers augmented slightly by natural gas. Wood fuel use $\left(264.56 \mathrm{OD} \mathrm{kg} / \mathrm{m}^{3}\right)$ was mainly comprised of bark. Electricity consumed onsite was calculated to be $276 \mathrm{kWh} / \mathrm{m}^{3}$, unallocated. Natural gas and propane were the primary fossil fuels used on site. Table 5 shows the onsite energy inputs for the mills in LSL manufacturing.

Table 5 Onsite energy inputs per $\mathrm{m}^{3}$ laminated strand lumber, North American average (unallocated).

\begin{tabular}{llll}
\hline Inputs & Quantity & $\begin{array}{l}\text { Weighted coefficient } \\
\text { of variation (\%) }\end{array}$ & Energy (MJ) \\
\hline Electricity & $276.01 \mathrm{kWh}$ & 1.27 & - \\
Wood fuel $^{\mathrm{a}}$ & $264.56 \mathrm{OD} \mathrm{kg}$ & 30.10 & 5529 \\
Propane $^{\mathrm{b}}$ & $9.78 \mathrm{~L}$ & 244.19 & 227 \\
Natural gas $^{\mathrm{c}}$ & $0.40 \mathrm{~m}^{3}$ & 81.13 & 15 \\
Diesel $^{\mathrm{d}}$ & $2.48 \mathrm{~L}$ & 1.08 & 89 \\
Gasoline $^{\mathrm{e}}$ & $0.01 \mathrm{~L}$ & 246.50 & $<1$ \\
\hline
\end{tabular}

Heating values of the inputs (MJ/unit): ${ }^{\mathrm{a}} 20.9,{ }^{\mathrm{b}} 23.2,{ }^{\mathrm{c}} 36.6,{ }^{\mathrm{d}} 36.0,{ }^{\mathrm{e}} 32.0$

A smaller $\mathrm{CoV}_{w}$ for electricity indicated the less spread around the mean, indicating a good data quality. Electricity from the grid was used to operate equipment within the plant, including conveyors, refiners, fan motors, hydraulic press motors, sanders, pumps, and emission control systems. The electricity use considered the weighted average of regional variations (75:25) during the development of the $\mathrm{LCl}: 75 \%$ from the electricity grid in Ontario, Canada $\left(\mathrm{CO}_{2}\right.$ emission factor $0.095 \mathrm{~kg} / \mathrm{kWh})$ and $25 \%$ from NPCC, US grid $\left(\mathrm{CO}_{2}\right.$ emission factor $\left.0.251 \mathrm{~kg} / \mathrm{kWh}\right)$ [38]. Wood fuel at $5,529 \mathrm{MJ} / \mathrm{m}^{3} \mathrm{LSL}$ was the primary heating source used in the LSL process, including heat for drying strands, steam or oil for log ponds, and hot pressing. In addition, fuels such as diesel, propane, and gasoline were used for handling material onsite. Onsite air emissions were derived from the surveyed mills along with pertinent emissions data categorized by the USEPA. When available, surveyed air emission data as primary data were selected rather than secondary data.

\subsection{Gate-to-Grave Model for LSL Products}

The assessment of cradle-to-grave life cycle impacts of engineered wood products is essential for understanding the environmental trade-offs as opposed to their counterparts. Therefore, a gate-tograve model was constructed and evaluated. The gate-to-grave stages of an average LSL product life cycle and the assumptions made are briefly described in this section. 


\subsubsection{LSL Product Transport (A4)}

LSL was transported to warehouses for distribution and then to installation sites. The LSL industry experts were contacted to confirm the data assumption on distance and mode of transportation [41]. This study assumed $80 \%$ and $20 \%$ of LSL was transported by rail and truck (i.e., diesel flatbed trailer), respectively. The distance between mills and warehouses was considered to be 1,000 $\mathrm{km}$. This value was based on the estimation of the location of production facilities to major consumer locations (i.e., major cities). The transportation distance between the warehouse and installation site was assumed to be $100 \mathrm{~km}$ [41]. These transportation values were a source of uncertainty and were assessed later for their sensitivity to the overall environmental impacts.

\subsubsection{Installation and Use of LSL (B1)}

LSL is mostly used in headers and beams, wall stud applications, roof beams and rafters, truss chords, rim boards, and stair stringers, etc. This phase included material and energy inputs in installing, using, and maintaining the LSL products. A 3\% loss in mass was assumed to account for the trimming and finishing process in consultation with the industry experts [41]. Further, it was assumed that no preservatives are used in LSL products owing to their intrinsic durability and no exterior exposure. A service life of 80 years was considered in the study with no added repair or maintenance inputs in the use phase until its removal at the end of the use phase.

\subsubsection{Disposal of LSL (C1-C4)}

Three disposal options were evaluated in this study. The options are listed below and described subsequently.

Option 1 (baseline): Buildings were demolished at 80 years and LSL, as waste was disposed of in a local landfill that captured methane.

Option 2: Buildings were demolished at 80 years and LSL; a waste was burned to generate heat to displace an equivalent amount of natural gas

Option 3: Buildings were deconstructed with the recovery of LSL. The recovered LSL was used for a second lifetime, assuming no decline in wood quality.

Landfill disposal was considered a common practice because of cost while indirectly offering an environmental advantage for carbon storage. The disposal phase of LSL consisted of the demolition (C1), transport to landfill-site (C2), processing of LSL waste (C3), and final disposal in the landfill. The contribution of the demolition phase (C1) to the environmental impacts of the whole LSL life cycle was considered negligible in this case [42-44]. Waste generated from the demolition was transported to a landfill site. The distance to the landfill location was taken as $40 \mathrm{~km}$, and a diesel dump truck was used to transport waste LSL from the demolition site. There was no further processing of LSL waste at the landfill and hence no contribution to environmental impacts. About $12 \%$ of wood decomposes anaerobically into gas when placed in the landfill [45], and wood content in LSL products was taken as $97 \%$ with $50 \%$ carbon by weight. Around $1,010 \mathrm{~kg} \mathrm{CO}$ eq long-term carbon storage was estimated for the cradle-to-grave life cycle of $1 \mathrm{~m}^{3}$ of LSL (Table 6). 
Table 6 Carbon storage per $\mathrm{m}^{3}$ of LSL (cradle-to-grave).

\begin{tabular}{ll}
\hline Parameter & Value (\%) \\
\hline Carbon breakdown in landfill & $12 \%$ \\
Carbon storage in landfill & $88 \%$ \\
Wood in LSL & $97 \%$ \\
Carbon content in LSL & $50 \%$ \\
Net long-term carbon storage (kg CO & eq) \\
\hline
\end{tabular}

Using methane capture technology, Table 7 shows the emissions of biogenic methane and carbon dioxide, primary components of landfill gas estimated using the WARM model from anaerobic storage of wood waste [45].

Table 7 GHG emissions from wood landfilled with standard methane capture.

\begin{tabular}{|c|c|c|}
\hline GHG Emissions & $\mathrm{Kg} / \mathrm{OD} \mathrm{kg}$ wood & $\mathrm{Kg} / \mathrm{m}^{3}$ of $\mathrm{LSL}$ \\
\hline Methane, biogenic ${ }^{1}$ & 0.0090 & 5.8249 \\
\hline Carbon dioxide, biogenic ${ }^{1}$ & 0.0303 & 19.5781 \\
\hline Carbon dioxide, biogenic ${ }^{2}$ & 0.1155 & 74.7528 \\
\hline Carbon dioxide, biogenic ${ }^{3}$ & 0.0495 & 32.0369 \\
\hline
\end{tabular}

${ }^{1}$ Released directly into the air. ${ }^{2}$ Released after energy recovery (70\%). ${ }^{3}$ Release after flaring (30\%)

- energy not recovered.

In the second disposal option, the generated heat from the burning LSL was assumed to displace an equivalent amount of natural gas. The higher heating value (HHV) of LSL wood was considered as $20.9 \mathrm{MJ} / \mathrm{kg}$ and a heating efficiency was taken as $70 \%$. The useful heat generated from burning LSL was 9,470 MJ. For natural gas, the assumed HHV was $38.3 \mathrm{MJ} / \mathrm{m}^{3}$, with a heating efficiency was $85 \%$. Based on this, $1 \mathrm{~m}^{3}$ of LSL can displace $291 \mathrm{~m}^{3}$ of natural gas.

The third disposal option assumed recovery of LSL from building deconstruction for reuse and thus considered resource efficient. Deconstruction is not common in North America due to the high cost of the deconstruction process and the lack of a robust market for the reuse of deconstructed wood [46]. However, recycling wood products would play an important role in the sustainable management of forest resources, given their increasing global demand [47, 48]. The LCl parameters are considered (Table 8) for the modeling of recycling and reuse of the LSL for a second functional life where it will displace the virgin LSL. The assumptions were taken in consultation with the wood industry experts [41] and were also supported by Bergman et al. [47] and Roussat et al [48]. The analysis considered no decline in wood quality and carbon stored in the wood when reused but with a $17 \%$ mass loss [47]. The waste generated after the second functional life from demolishing was considered through the landfill route.

Table 8 Inputs for $1 \mathrm{~m}^{3}$ laminated strand lumber (LSL) recovered and reused [47].

\begin{tabular}{lll}
\hline Inputs parameter & Value & Unit \\
\hline 1. Removal (deconstruction) & & \\
\hline
\end{tabular}




\begin{tabular}{lll}
\hline Losses in recovery & 17 & $\%$ \\
LSL removed & 684.15 & OD kg \\
Disposal: Landfilled with methane capture & 110.03 & OD kg \\
Transport, Single unit truck, gasoline-powered/US & 0.62 & $\mathrm{tkm}$ \\
Transport, Single unit truck, diesel-powered/US & 0.51 & $\mathrm{tkm}$ \\
Gasoline, combusted in equipment/US & 1.53 & $\mathrm{liter}$ \\
Electricity, at grid, US/US & 14.3 & $\mathrm{kWh}$ \\
2. Storage & & \\
Transport, Single unit truck, gasoline-powered/US & 17.10 & $\mathrm{tkm}$ \\
Transport, Single unit truck, diesel-powered/US & 17.10 & $\mathrm{tkm}$ \\
Electricity, at grid, US/US & 2.86 & $\mathrm{kWh}$ \\
Residual fuel oil, combusted in industrial boiler/US & 0.22 & $\mathrm{liter}$ \\
Natural gas, combusted in industrial boiler/US & 0.00009 & $\mathrm{~m}$ \\
Gasoline, combusted in equipment/US & 1.44 & $\mathrm{liter}$ \\
3. Product Transport & & \\
Transport, Single unit truck, diesel-powered/US & 32.84 & $\mathrm{tkm}$ \\
\hline
\end{tabular}

\subsection{Data Quality}

This study collected data (cradle-to-gate) from LSL manufacturers in North America that used average technology. Primary data for the LCl collected through surveys followed the ISO 14040 standard. The production facilities surveyed were selected to be representative $(100 \%$ of the total LSL industry) of North American production practices. A mass balance was performed for the two plants for data quality assurance. The mass allocations approach was used to assign environmental impacts to the product (e.g., LSL) and co-products (e.g., mill residues sold to outside customers). The inventory data for gate-to-grave stages were collected based on consultations with industry experts and was supported by other studies on wood products $[47,48]$. It was assumed to represent the average scenario of LSL transport from mill, installation and use, and disposal at the end of life.

\subsection{Life Cycle Impact Assessment (LCIA) Method}

The LCIA phase establishes links between the $\mathrm{LCl}$ results and potential environmental impacts. The magnitude and significance of the potential environmental impacts as a set of indicators are evaluated using the TRACI [49], CML [50], and CED [51] methods available in the SimaPro software (version 9.1). Each impact indicator is a measure of an aspect of a potential impact. The LCIA phase in this study included only the mandatory steps: classification and characterization. The normalization and weighting steps were not in the scope of the study. The study does not make value judgments about the impact indicators, meaning comparison indicator values are not valid. Additionally, each impact indicator value is stated in units that are not comparable to others. For the same reasons, indicators should not be combined or added. The LCIA results were intended to be used for the identification of hotspots in the LSL systems (cradle-to-gate and cradle-to-grave) studied. The required indicators recommended by the PCR and ISO 21930 were also included in the assessment. The primary fuels were categorized into non-renewable (fossil and nuclear) and renewable (biomass, geothermal, solar, wind, hydro). 


\section{Results and Discussions}

\subsection{LCIA Results}

Figure 3 shows the relative contribution of cradle-to-gate and gate-to-grave lifecycle stages towards the total environmental impacts of LSL. The gate-to-grave lifecycle stages made a significant contribution (e.g., $\sim 44 \%$ to LSL's total GW impact) to overall LCA results, which provide the importance of including the whole life cycle in the LCA of wood products. The fossil fuel depletion impacts showed substitution benefits of landfill gas capture and energy recovery (disposal option 1).

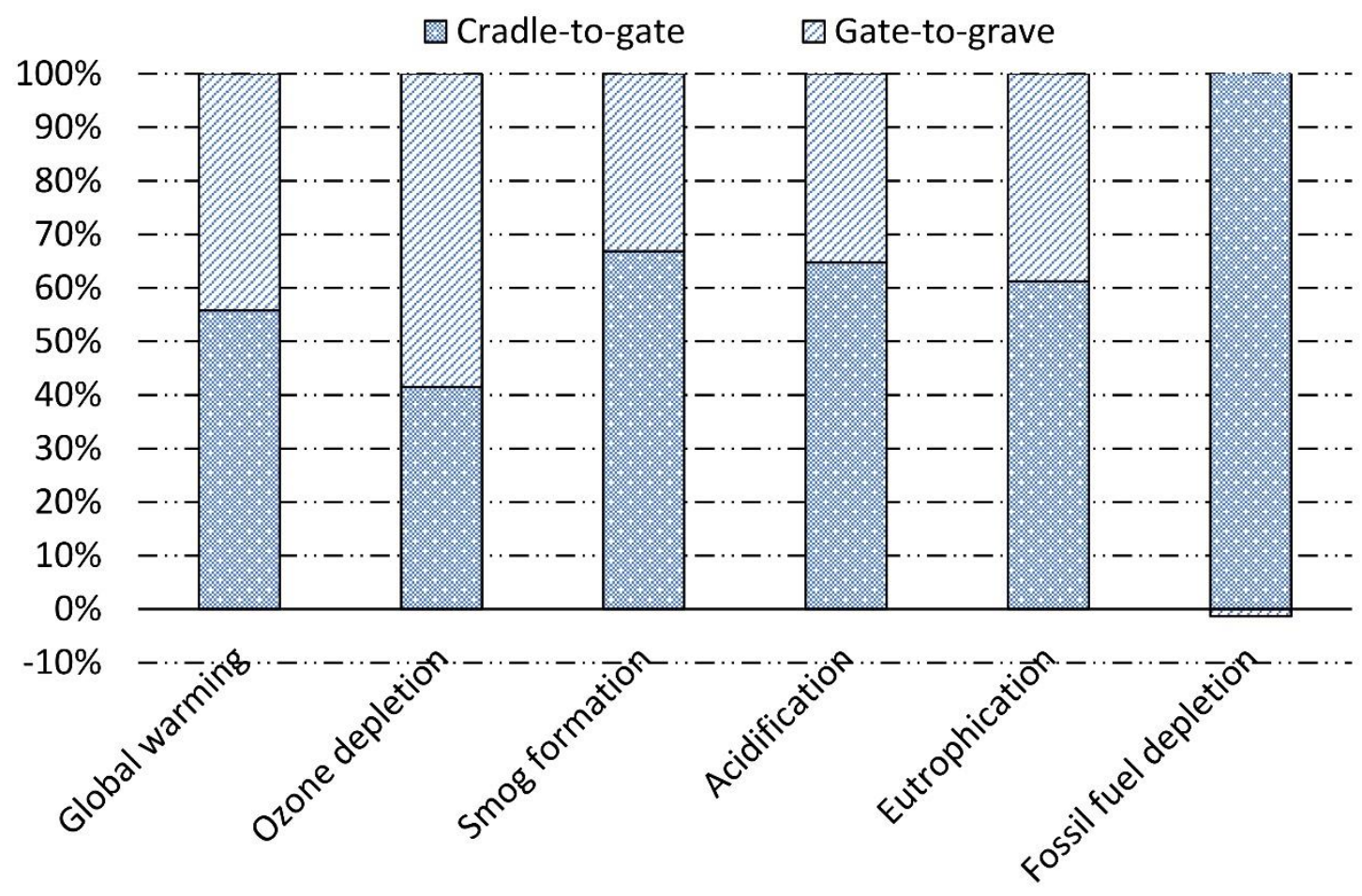

Figure 3 Percent share of cradle-to-gate and gate-to-grave lifecycle stages in the overall environmental impacts of LSL.

The overall LCA results (with absolute values of the impact indicators and percentage contribution of the individual lifecycle stages) were presented in Table 9. Certain impact indicators such as water use, solid waste was were only based on $\mathrm{LCl}$ indicator results. 
Table 9 Summary of life cycle environmental impacts per $\mathrm{m}^{3}$ of laminated strand lumber produced in North America (mass allocation).

\begin{tabular}{|c|c|c|c|c|c|c|c|c|c|c|}
\hline Impact category & LCIA Method & $\begin{array}{l}\text { Cradle-to-grave } \\
\text { (A1-C4) }\end{array}$ & $\begin{array}{l}\text { Cradle- } \\
\text { to-gate } \\
\text { (A1-A3) }\end{array}$ & $\begin{array}{l}\text { A1 } \\
\text { (\%) }\end{array}$ & $\begin{array}{l}A 2 \\
(\%)\end{array}$ & $\begin{array}{l}\text { A3 } \\
\text { (\%) }\end{array}$ & $\begin{array}{l}\text { Gate-to- } \\
\text { grave } \\
\text { (A4-C4) }\end{array}$ & $\begin{array}{l}\text { A4 } \\
(\%)\end{array}$ & $\begin{array}{l}\text { B1 } \\
\text { (\%) }\end{array}$ & $\begin{array}{l}\text { C1-C4 } \\
(\%)\end{array}$ \\
\hline \multicolumn{11}{|l|}{ Core mandatory impact indicators } \\
\hline Global warming $\left(\mathrm{kg} \mathrm{CO}_{2} \mathrm{eq}\right)$ & TRACI 2.1 & 492.92 & 274.9 & 55.70 & 21.45 & 22.85 & 218.02 & 42 & 0 & 58 \\
\hline $\begin{array}{l}\text { Ozone layer depletion (kg CFC-11 } \\
\text { eq) }\end{array}$ & TRACI 2.1 & $1.62 \mathrm{E}-05$ & $6.72 \mathrm{E}-06$ & 1.82 & 1.54 & 96.64 & $9.00 \mathrm{E}-06$ & 95 & 0 & 5 \\
\hline Acidification ( $\mathrm{kg} \mathrm{SO}_{2}$ eq) & TRACI 2.1 & 2.54 & 1.7 & 53.07 & 21.43 & 25.50 & 0.84 & 95 & 0 & 5 \\
\hline Eutrophication (kg N eq) & TRACI 2.1 & 0.31 & 0.2 & 41.26 & 16.37 & 42.37 & 0.11 & 97 & 0 & 3 \\
\hline Smog formation $\left(\mathrm{kg} \mathrm{O}_{3} \mathrm{eq}\right)$ & TRACI 2.1 & 64.50 & 39.51 & 45.37 & 27.04 & 27.59 & 24.99 & 94 & 0 & 6 \\
\hline Abiotic depletion (MJ, NCV) & CML baseline & 4114.15 & $4,015.88$ & 66.43 & 18.37 & 15.20 & 98.27 & 849 & 0 & -749 \\
\hline Fossil fuel depletion (MJ Surplus) & TRAC 2.1 & 590.14 & 597.92 & 65.97 & 18.53 & 15.50 & -7.78 & -1502 & 0 & 1602 \\
\hline \multicolumn{11}{|l|}{ Use of primary resources } \\
\hline $\begin{array}{l}\text { Renewable primary energy carrier } \\
\text { used as energy (MJ, NCV) }\end{array}$ & CED & 5201.13 & $5,190.65$ & 0.49 & 0.03 & 99.48 & 10.48 & 95 & 0 & 5 \\
\hline $\begin{array}{l}\text { Renewable primary energy carrier } \\
\text { used as material (MJ, NCV) }\end{array}$ & CED & 13063.02 & $13,063.02$ & 100 & 0 & 0 & 0.00 & 0 & 0 & 0 \\
\hline $\begin{array}{l}\text { Non-renewable primary energy } \\
\text { carrier used as energy (MJ, NCV) }\end{array}$ & CED & 6649.93 & $6,512.45$ & 45 & 11 & 43 & 137.48 & 633 & 0 & -533 \\
\hline $\begin{array}{l}\text { Non-renewable primary energy } \\
\text { carrier used as material (MJ, NCV) }\end{array}$ & CED & 1100.11 & 1100.11 & 0 & 0 & 100 & 0 & 0 & 0 & 0 \\
\hline Total (MJ, NCV) & CED & 26014.19 & 25866.23 & & & & 147.96 & & & \\
\hline \multicolumn{11}{|l|}{ Mandatory inventory parameters } \\
\hline $\begin{array}{l}\text { Consumption of freshwater } \\
\text { resources }\left(\mathrm{m}^{3}\right)\end{array}$ & $\mathrm{LCl}$ indicator & 8.18 & 5.4 & 48.70 & 0.19 & 51.11 & 2.8 & 0 & 0 & 100 \\
\hline Indicators describing waste & & & & & & & & & & \\
\hline
\end{tabular}


Recent Progress in Materials 2021; 3(4), doi:10.21926/rpm.2104048

\begin{tabular}{|c|c|c|c|c|c|c|c|c|c|c|}
\hline Hazardous waste disposed (kg) & $\mathrm{LCl}$ indicator & 0.63 & $6.02 \mathrm{E}-01$ & 92.03 & 0.01 & 7.84 & $3.11 E-02$ & 0 & 0 & 100 \\
\hline Non-hazardous waste disposed (kg) & $\mathrm{LCl}$ indicator & 31.55 & $2.96 \mathrm{E}+01$ & 1.87 & 0.00 & 97.97 & $1.95 E+00$ & 96 & 0 & 4 \\
\hline $\begin{array}{l}\text { High-level radioactive waste, } \\
\text { conditioned, to final repository } \\
\left(\mathrm{m}^{3}\right)\end{array}$ & $\mathrm{LCl}$ indicator & 1.57E-05 & $1.57 \mathrm{E}-05$ & 0.00 & 0.00 & 100.00 & $0.00 E+00$ & 0 & 0 & 0 \\
\hline $\begin{array}{l}\text { Intermediate- and low-level } \\
\text { radioactive waste conditioned, to } \\
\text { final repository }\left(\mathrm{m}^{3}\right)\end{array}$ & $\mathrm{LCl}$ indicator & $2.36 \mathrm{E}-05$ & $2.34 \mathrm{E}-05$ & 0.21 & 0.24 & 99.57 & $1.70 \mathrm{E}-07$ & 0.00 & 0 & 100 \\
\hline
\end{tabular}


The most relevant lifecycle stages in their decreasing contribution to their cradle-to-grave GW impacts were resource extraction (A1), end-of-life (EoL), transportation [resources (A2) and product (A4)], and LSL manufacturing(A3). Further, the breakdown of characterization results by life cycle stages is shown in Figure 4, where the most significant unit processes (hotspots) were identified for different impact categories as well as for different life cycle stages.

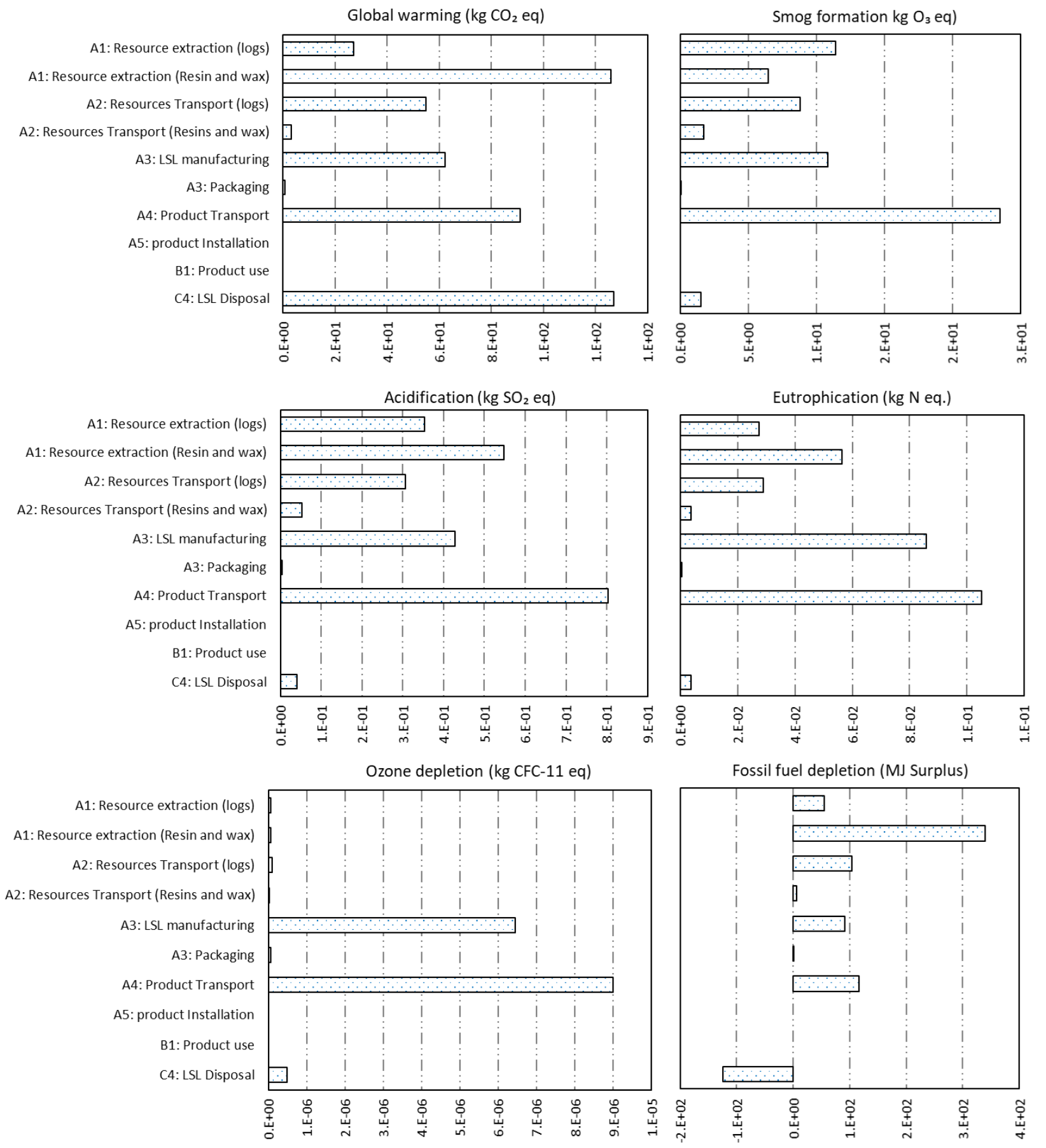

Figure 4 Characterization impacts of different life cycle stages with disposal option 1. 


\subsubsection{Global Warming (GW)}

The cradle-to-grave GW impact was $493 \mathrm{~kg} \mathrm{CO}_{2}$ eq for $1 \mathrm{~m}^{3} \mathrm{LSL}$. Around $56 \%$ and $44 \%$ of total GW impacts of LSL were contributed by cradle-to-gate and gate-to-grave life cycle stages (Table 9). In the cradle-to-gate $\mathrm{GW}$ impacts (around $275 \mathrm{~kg} \mathrm{CO} 2 \mathrm{eq} / \mathrm{m}^{3}$ ), the major contribution was from the resource extraction stage [A1] (55.7\%), especially from the resin and wax (126 kg CO 2 eq) and forest resources (27 $\mathrm{kg} \mathrm{CO}_{2}$ eq) (Figure 4). The use of resin and wax in the manufacturing stage was identified as a hotspot, noting the need for environment-friendly alternatives for this role. Transport activities [A2] caused $22 \%$ of the GW impacts in cradle-to-gate LCA results. The transportation [A4] had a much greater contribution (42\%) in gate-to-grave GW impacts. Longer transport distances between the mill and LSL installation site $(1000 \mathrm{~km}$ from LSL mill to warehouse $+100 \mathrm{~km}$ from warehouse to installation site) increased their share in the gate-to-grave GW impacts. Here, the increasing demand for the use of engineered woods like LSL in the residential sector had drawn attention to sustainable logistics and supply chain management which needs to be studied in the future.

Another major hotspot was the landfill disposal ( $127 \mathrm{~kg} \mathrm{CO}_{2}$ eq), contributing $58 \%$ to the gateto-grave model and $23 \%$ to the total GWP. The anaerobic decomposition of LSL results in the release of landfill gases. It was estimated (Table 7) that $5.82 \mathrm{~kg} \mathrm{CH} / \mathrm{m}^{3}$ of LSL $\left(25 \%\right.$ of total $\mathrm{CH}_{4}$ generated in the landfills) to be released into the atmosphere from the landfill disposal option and thus contributed to high GW impact. However, it was realized that the magnitude of these impacts could change if the recycling of LSL waste or any other disposal method like incineration was considered. Recycling LSL could increase the life of carbon stored in the LSL product. However, only one functional life was considered in this study. A comparative evaluation of variation in disposal mechanisms is presented later in the paper.

\subsubsection{Smog Formation (SF)}

The smog formation (SF) impacts were associated with the formation of photochemical oxidants. The cradle-to-gate and gate-to-grave stages shared $67 \%$ and $33 \%$ of the total SF impacts of the LSL $\left(64.50 \mathrm{~kg} \mathrm{O} \mathrm{O}_{3} \mathrm{eq} / \mathrm{m}^{3}\right)$, respectively. In this study, the SF impacts were mainly caused by emissions of $\mathrm{NO}_{\mathrm{x}}$, hydrocarbons in transportation activities, and VOCs released from the solvents in the used resin and wax (Figure 4). All these life cycle stages (A1-A4) contributed 98\% to the total SF impacts. The resource extraction for both logs and the resin and wax [A1] and their transportation [A2] were identified as major hotspots in SF impacts of cradle-to-gate stages. The LSL manufacturing was caused nearly $28 \%$ of the SF impacts. The influence of change in the adhesive used in LSL manufacturing and feedstock transportation distances was further studied in the sensitivity analysis (Section 3.4). The product transportation [A2] had the largest SF impact (94\%) in the gate-to-grave life cycle stage of LSL, which came from fuel use in the transportation process.

\subsubsection{Acidification (AC)}

The overall acidification (AC) impact of the studied LSL system was $2.54 \mathrm{~kg} \mathrm{SO} \mathrm{eq} / \mathrm{m}^{3}$. The cradleto-gate and gate-to-grave stages contributed $65 \%$ and $35 \%$ of the total AC impacts, respectively. The AC impacts were mainly caused by emissions of nitrogen oxides $\left(\mathrm{NO}_{\mathrm{x}}\right)$ and sulfur dioxide $\left(\mathrm{SO}_{2}\right)$. The $\mathrm{SO}_{2}$ emissions were primarily from the combustion of fossil fuels for energy requirements at 
the mill and fuel burned in the transportation processes. The source of these acidifying emissions was resource extraction (36\%), product transportation (32\%), and resource transportation (14\%) stages, together accounting for $81 \%$ of the total AC impacts. In the LSL manufacturing facility, the $\mathrm{NO}_{\mathrm{x}}$ emissions were mainly caused by the provision of energy for LSL production.

\subsubsection{Eutrophication (EU)}

The cradle-to-grave eutrophication (EU) impacts of LSL was $0.31 \mathrm{~kg} \mathrm{~N} \mathrm{eq} / \mathrm{m}^{3}$ (61\% from cradleto-gate and $39 \%$ from gate-to-grave). Within the cradle-to-gate results, the LSL manufacturing and resource extraction processes were the major contributors to EU impacts (Figure 4). The emissions from the provision of required energy and adhesives in the LSL manufacturing [A3] caused $42 \%$ of the cradle-to-gate EU impacts. The $\mathrm{NO}_{x}$ emissions, the main source of EU impacts, were released during the harvesting of wood feedstock and production of adhesives. The product transportation [A2] stage contributed $97 \%$ of gate-to-grave EU impacts which were mostly derived from the combustion of fuels.

\subsubsection{Ozone Depletion (OZD)}

Referring to the ozone depletion (OZD) impacts of the analyzed LSL system, the share of cradleto-gate and gate-to-grave impacts was $41 \%$ and $59 \%$, respectively. Among all life stages, transportation of LSL product (A4) and LSL manufacturing (A3) were the major hotspots contributing $56 \%$ and $40 \%$ of cradle-to-grave OZD impacts, respectively. In the cradle-to-gate LCA results, the LSL manufacturing stage [A3] caused most (96\%) of the OZD impacts. The sources of OZD emissions were the use of antifreeze coolants, adhesives, and wax. Releases of chemicals influencing ozone depletion were reported in a very small quantity in terms of absolute values, but they have a high OZD. Use of such inputs cannot be avoided in the manufacturing of wood products, however, the alternative with lower OZD needs to be investigated in detail. In gate-to-grave, it was the LSL transportation stage [A4] that contributed nearly $95 \%$ of the OZD impacts.

\subsubsection{Fossil Fuel Depletion (FFD)}

Figure 4 shows the breakdown of FFD contribution by each life cycle stage. The Fossil fuel depletion (FFD) impact of the analyzed LSL system was $590 \mathrm{MJ} / \mathrm{m}^{3}$. The major contribution was observed in the resource extraction stage. In the cradle-to-gate, the resource extraction stage accounted for $66 \%$ of the impacts. The FFD in the resource extraction processes for resins and wax (339 MJ) was much greater than the harvesting activities in forest resources (60 MJ). FFD impact of the LSL manufacturing stage ( $6 \mathrm{MJ}$ ) was relatively small due to the use of mill residues for energy production, which subsequently reduced the use of fossil fuels. The FFD impact from the transportation product [A4] was $118 \mathrm{MJ}$ and mostly came from the use of fossil fuel in transport equipment. A negative FFD was noticed in the gate-to-grave stage due to methane recovery in the landfill. The generated landfill gas was considered captured in the disposal of LSL products that offset fossil fuel use to an extent (-125 MJ). 


\subsection{Comparison of LSL Waste Disposal Options}

Table 10 presents the environmental impacts of individual EoL or disposal options [as well as the whole life cycle (cradle-to-grave) of LSL] considering the substitution benefits (i.e., natural gas displaced by fuels/energy generated in the disposal of LSL and virgin-LSL products by recovery LSL at the $1^{\text {st }}$ EoL of $\left.L S L\right)$. The absolute values of GW and FFD impacts were negative for option 2 due to a large amount of natural gas being substituted by energy generated from the burning of LSL at the EoL. For option 3, all impact categories values were negatives except FFD as LSL was recovered and reused and negligible energy was recovered. Considering the whole life cycle (cradle-to-grave), the burning of LSL waste (option 2) resulted in negative GW impacts owing to the largest substitution benefits of generated heat that replaces natural gas.

Table 10 Environmental impacts of LSL waste disposal options.

\begin{tabular}{|c|c|c|c|c|c|c|}
\hline \multirow[b]{2}{*}{ Impact category } & \multicolumn{3}{|c|}{ Impacts of disposal options (C4) } & \multicolumn{3}{|c|}{$\begin{array}{c}\text { Cradle-to-grave impacts with each } \\
\text { disposal option (A1-C4) }\end{array}$} \\
\hline & $\begin{array}{l}\text { Landfill } \\
\text { disposal } \\
\text { (Option 1) }\end{array}$ & $\begin{array}{l}\text { LSL waste } \\
\text { burning } \\
\text { (Option 2) }\end{array}$ & $\begin{array}{l}\text { LSL recovery } \\
\text { for reuse } \\
\text { (Option 3) }\end{array}$ & Option 1 & Option 2 & Option 3† \\
\hline $\mathrm{GW}\left(\mathrm{kg} \mathrm{CO} \mathrm{C}_{2}\right.$ eq) & $1.27 E+02$ & $-7.12 \mathrm{E}+02$ & $-1.59 \mathrm{E}+02$ & $4.93 E+02$ & $-3.47 E+02$ & $2.07 E+02$ \\
\hline OZD (kg CFC-11eq) & $4.86 \mathrm{E}-07$ & $9.55 \mathrm{E}-05$ & $-7.42 \mathrm{E}-06$ & $1.62 \mathrm{E}-05$ & $1.11 \mathrm{E}-04$ & 8.30E-06 \\
\hline $\mathrm{SF}\left(\mathrm{kg} \mathrm{O}_{3} \mathrm{eq}\right)$ & $1.51 \mathrm{E}+00$ & $3.60 \mathrm{E}+00$ & $-1.74 \mathrm{E}+01$ & $6.45 E+01$ & $6.66 \mathrm{E}+01$ & $4.56 \mathrm{E}+01$ \\
\hline $\mathrm{AC}\left(\mathrm{kg} \mathrm{SO} \mathrm{S}_{2} \mathrm{eq}\right)$ & $4.11 \mathrm{E}-02$ & 4.29E-02 & $-5.51 E-01$ & $2.54 \mathrm{E}+00$ & $2.55 E+00$ & $1.95 \mathrm{E}+00$ \\
\hline EU (kg N eq) & 3.77E-03 & $4.58 \mathrm{E}-01$ & $-4.91 E-02$ & 3.09E-01 & $7.63 \mathrm{E}-01$ & $2.56 \mathrm{E}-01$ \\
\hline FFD (MJ Surplus) & $-1.25 \mathrm{E}+02$ & $-1.69 E+03$ & $3.84 \mathrm{E}+01$ & $5.90 \mathrm{E}+02$ & $-9.80 \mathrm{E}+02$ & $7.53 \mathrm{E}+02$ \\
\hline \multicolumn{4}{|c|}{ Net carbon storage $\left(\mathrm{kg} \mathrm{CO}_{2} \mathrm{eq}\right) \ddagger$} & $1.01 \mathrm{E}+03$ & - & $1.32 \mathrm{E}+03$ \\
\hline
\end{tabular}

tIncludes landfill disposal after the end of second useful life

¥Carbon stored in the product and landfill

The landfill disposal has the highest $\mathrm{GW}$ impacts caused by the $\mathrm{GHG}$ released (i.e., $\mathrm{CH}_{4}$ ) due to the anaerobic decomposition of LSL waste. Option 3 has GW impacts coming from the operations in the recovery of LSL and product transportation to and from storage. Considering carbon storage, options 1 (stored 1,010 $\mathrm{kg} \mathrm{CO}_{2}$ eq in landfill) and 2 (stored 1,320 $\mathrm{kg} \mathrm{CO}_{2}$ eq in product and landfill) are better than option 2. In option 2, atmospheric carbon stored in the wood was released into the atmosphere during the burning process. In OZD impacts, the burning scenario was performing worse than the other two because of the emission of ozone-depleting substances in the burning of LSL waste laden with adhesives. It was similar order for SF impacts with higher impacts from burning of LSL followed by recovery and reuse. The emissions of $\mathrm{VOC}_{S}, \mathrm{NO}_{\mathrm{x}}$, and hydrocarbons cause higher $\mathrm{SF}$ impacts. In the AC category, most of the contribution was from emissions of $\mathrm{NO}_{x}$ and $\mathrm{SO}_{2}$ coming mainly from the transportation activities which were almost similar for option 1 and option 2 . 


\subsection{Biogenic Carbon Uptake and Release}

Wood is a biobased product and contains biogenic carbon. ISO 21930 provides set rules for accounting for biogenic carbon flows. The biogenic carbon flows ( $\mathrm{kg} \mathrm{CO}_{2}$ eq.) to and from the environment were listed in inventory Table 11.

Table $11 \mathrm{LCl}$ flows related to biogenic carbon uptake and release.

\begin{tabular}{|c|c|c|c|c|c|}
\hline $\begin{array}{l}\text { Details of biogenic carbon } \\
\text { flows }\left(\mathrm{kg} \mathrm{CO} \mathrm{CO}_{2} \text { eq) }\right.\end{array}$ & A1 & $\mathrm{A} 2$ & $\begin{array}{l}\text { A3 } \\
\text { (manufacturing) }\end{array}$ & $\begin{array}{l}\text { A3 } \\
\text { (packaging) }\end{array}$ & C4 \\
\hline $\begin{array}{l}\text { Biogenic Carbon Removal } \\
\text { from Product }\end{array}$ & -1754.05 & - & - & - & - \\
\hline $\begin{array}{l}\text { Biogenic Carbon Emission } \\
\text { from Products (including } 1269.02 \\
\text { residues) }\end{array}$ & - & - & 123.14 & - & 1145.88 \\
\hline $\begin{array}{l}\text { Biogenic Carbon Removal } \\
\text { from Packaging }\end{array}$ & - & - & -1.00 & - & - \\
\hline $\begin{array}{l}\text { Biogenic Carbon Emission } 0.16 \\
\text { from Packaging }\end{array}$ & - & - & - & 0.16 & - \\
\hline $\begin{array}{l}\text { Biogenic Carbon Emission } \\
\text { from biomass boiler } 485.03 \\
\text { (Internal heat) }\end{array}$ & - & - & 485.03 & - & - \\
\hline
\end{tabular}

One $\mathrm{kg}$ of OD wood containing $0.5 \mathrm{~kg}$ carbon (assuming $50 \%$ carbon content) is equivalent to $1.83 \mathrm{~kg} \mathrm{CO}$ eq. The $\mathrm{CO}_{2}$ uptake by the forests was considered as negative emission (-1). The release of the $\mathrm{CO}_{2}$ as the main product (LSL), co-products, and combustion emissions in the manufacturing mill (A3) were treated as positive emissions (+1). This $-1 /+1$ approach helped in accounting for all biogenic carbon flows. The remaining GHG gases were characterized according to their global warming potentials. According to the ISO 21930, the biogenic carbon flow in LSL manufacturing and LSL packaging were reported separately (Table 11). The production of $647.21 \mathrm{~kg} \mathrm{LSL}\left(1 \mathrm{~m}^{3}\right)$ resulted in biogenic carbon removal equal to $-1754.05 \mathrm{~kg} \mathrm{CO} 2$ eq. About $+1145.88 \mathrm{~kg} \mathrm{CO}_{2}$ eq carbon was in the LSL product. Overall, $1269.02 \mathrm{~kg} \mathrm{CO}_{2}$ eq. (including $123.14 \mathrm{~kg} \mathrm{CO}_{2}$ eq. as co-products) biogenic carbon was emitted in the $\mathrm{A} 3$ stage as the main product and co-product.

\subsection{Sensitivity Analysis}

Figure 5 shows the variations in the environmental impacts of LSL due to changes in the major input parameters in the LCA study. A 20\% change in feedstock transport distance impacted the SF impact indicator most (5\%) followed by a $4 \%$ change in GW, AC, and AD indicators. EU and NRPRE showed a $2 \%$ change in absolute values. 


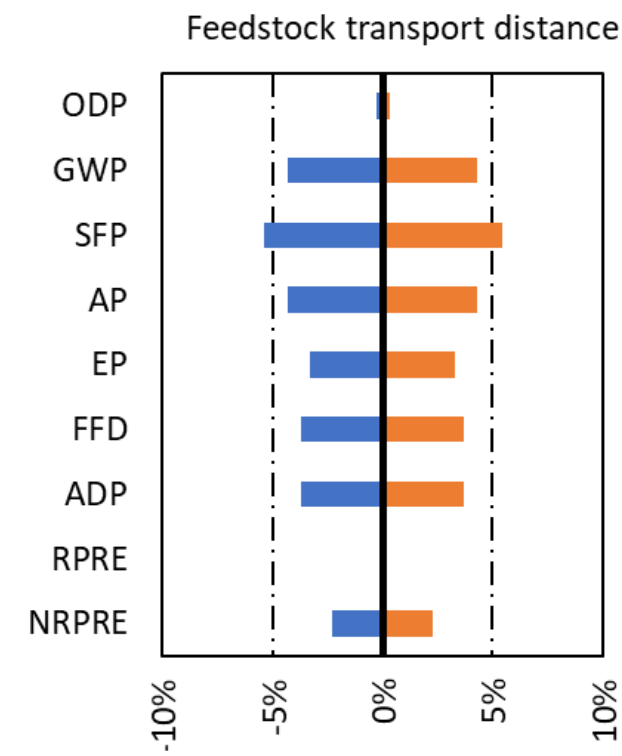

Adhesive use

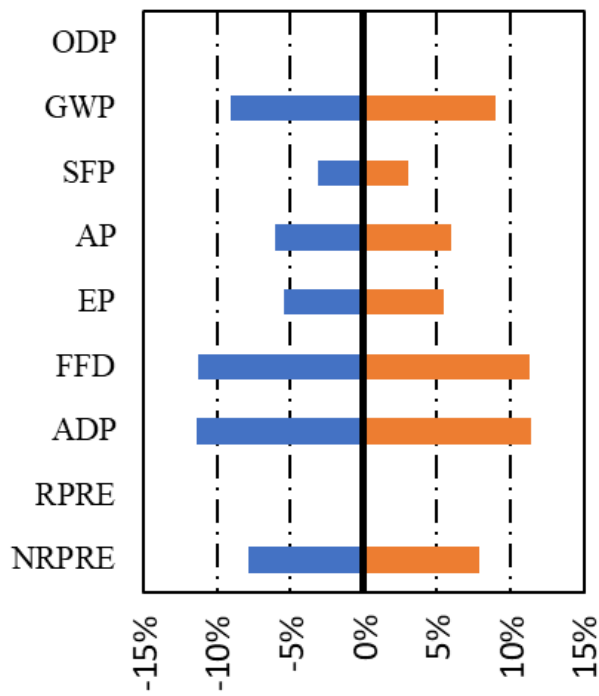

Electricity

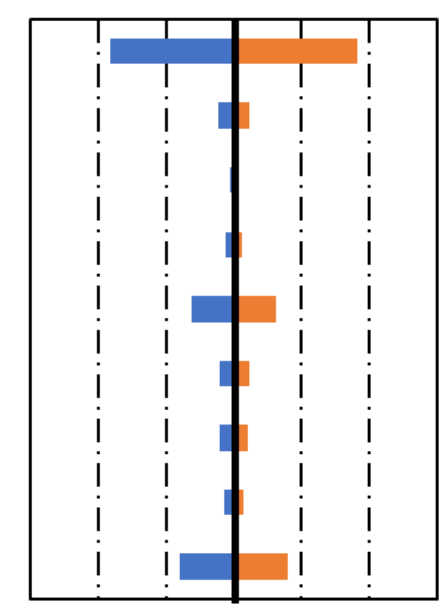

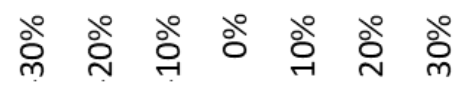

Wood fuel

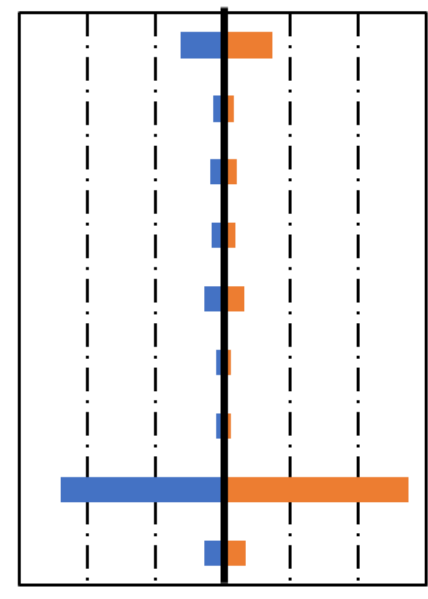

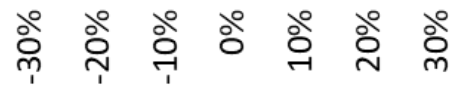

Figure 5 Influence of $20 \%$ change in input parameters on cradle-to-grave LCA results per $\mathrm{m}^{3}$ LSL. (OZD: ozone depletion, GW: global warming, SF: smog formation, AC: acidification, EU: eutrophication, FFD: fossil fuel depletion, AD: abiotic depletion, RPRE: renewable primary resources as energy, NRPRE: non-renewable primary resources as energy).

Given that transportation was the main contributor to these impact indicators, an improvement opportunity can be identified from the sensitivity analysis. The change in electricity inputs showed significant changes in OZD, NRPRE, and EU indicators, $18 \%, 8 \%$, and $6 \%$, respectively. The amount of adhesive used in the LSL impacted mostly GW, ADP, and NRPRE. A 20\% increase or decrease in the quantity of adhesive used in LSL influenced all impact categories, especially an $8-11 \%$ increase or decrease in the values of AD, FFD, GW, and NRPRE. The only impact category RPRE was sensitive to the amount of wood fuel used in the LSL production. The influence of increasing or decreasing the wood fuel use did not have much influence on the impact category results except the RPRE indicator, which reflects the share of renewable fuels being used as a primary energy source. 


\section{Conclusions}

Wood products are renewable and have much lower environmental impacts compared to fossil alternatives. This study performed an LCA to quantify the cradle-to-gate and cradle-to-grave environmental impacts of LSL products by following the guidelines of ISO 14000 and PCR. Also, three EoL options are compared which included landfill disposal (option 1: base case), burning to generate heat (option 2), and recovery and reuse of LSL products (option 3). Primary data was collected from manufacturers of LSL and the remaining data requirement were supplemented from literature. The functional unit was considered as $1 \mathrm{~m}^{3}$ of LSL produced, used, and disposed of at the EoL. Irrespective of indicators, the cradle-to-gate stage contributed more than half towards LSL's cradleto-grave environmental impacts. The cradle-to-grave GW impacts of LSL was $493 \mathrm{~kg} \mathrm{CO}{ }_{2} \mathrm{eq} / \mathrm{m}^{3}$ ( $56 \%$ and $44 \%$ were from cradle-to-gate and gate-to-grave life cycle stages, respectively). In the cradleto-gate stage of LSL, the hotspot was the resource extraction stage which included activities to produce logs as well as resins and wax. In the gate-to-grave, LSL transportation (A4) was the main hotspot mainly because of the long transportation distances from manufacturing sites to installation. Among the three LSL disposal options compared, the cradle-to-grave GW impacts and FFD of LSL in option 2 were negative and outperformed the other two disposal options. In the rest of the impact categories (OZD, SF, AC, and EU), option 3 (recovery and reuse of LSL) outperformed the other two disposal options. Moreover, EoL options 1 and 3 stored about 1,010 and 1,320 kg CO 2 eq carbon stored in the product and/or landfill, respectively. The long-term carbon storage value was about twice the cradle-to-grave GW impact of LSL. The quantity of adhesive used in LSL manufacturing influenced most of the impact indicators in sensitivity analysis results. Ensuring the optimal adhesive use in LSL manufacturing would improve LSL's environmental performance. Overall, this study showed that LSL had very low or negative GW impacts and carbon storage attributes would favor the wood products when substitution with other non-wood materials would be considered.

\section{Acknowledgments}

We gratefully acknowledge those LSL-producing companies and their employees that participated in the surveys to obtain production data.

\section{Author Contributions}

K.S. and R.B. came with the project and research idea; K.S. and R.B. designed the project and modeling approach; K.S. performed the modeling and analyzed the results; K.S., R.B, and M.P. reviewed the results. K.S., R.B, and P.K. developed the manuscript's structure and wrote the manuscript; all authors contributed to revising and editing the manuscript; and project administration and funding acquisition for the study was done by R.B.

\section{Funding}

This project is financially supported by a joint venture agreement between the USDA Forest Service Forest Products Laboratory and the U.S. Endowment for Forestry \& Communities, Inc., Endowment Green Building Partnership-Phase 1, no. 18-JV-11111137-021. 


\section{Competing Interests}

The authors declare no conflict of interest.

\section{References}

1. Bringezu S, Ramaswami A, Schandl H, O’Brie M, Pelto R, Acquatella J, et al. Assessing global resource use: A systems approach to resource efficiency and pollution reduction. Nairobi: International Resource Panel; 2017.

2. Abergel T, Dean B, Dulac J. Towards a zero-emission, efficient, and resilient buildings and construction sector: Global status report 2017. Paris: UN Environment; 2017.

3. U.S. Energy Information Administration. The United States consumed a record amount of renewable energy in 2020 [Internet]. Washington DC: U.S. Energy Information Administration; 2021 [cited date 2021 June 17]. Available from: https://www.eia.gov/todayinenergy/detail.php?id=48396\&src=email.

4. Oliver CD, Nassar NT, Lippke BR, McCarter JB. Carbon, fossil fuel, and biodiversity mitigation with wood and forests. J Sustain For. 2014; 33: 248-275.

5. Ritter MA, Skog K, Bergman R. Science supporting the economic and environmental benefits of using wood and wood products in green building construction. Madison, WI: U.S. Dept. of Agriculture, Forest Service, Forest Products Laboratory; 2011; FPL-GTR-206.

6. Johnston CMT, Radeloff VC. Global mitigation potential of carbon stored in harvested wood products. Proc Natl Acad Sci USA. 2019; 116: 14526-14531.

7. Brashaw B, Bergman R. Chapter 1: Wood as a renewable and sustainable resource [Internet]. Madison: U.S. Department of Agriculture; 2021 [cited date 2021 June 15]. Available from: https://www.fs.usda.gov/treesearch/pubs/62241.

8. Kutnar A, Hill C. Assessment of carbon footprinting in the wood industry. In: Assessment of carbon footprint in different industrial sectors, volume 2. 1st ed. Singapore: Springer; 2014. pp.135-172.

9. Milner HR. Sustainability of engineered wood products in construction. In: Sustainability of construction materials. 1st ed. Sawston: Woodhead Publishing; 2009. pp.184-212.

10. Sotayo A, Bradley D, Bather M, Sareh P, Oudjene M, El-Houjeyri I, et al. Review of state of the art of dowel laminated timber members and densified wood materials as sustainable engineered wood products for construction and building applications. Dev Built Environ. 2020; 1: 100004.

11. Stark NM, Cai Z. Chapter 11: Wood-based composite materials: Panel products, glued laminated timber, structural composite lumber, and wood-nonwood composites. In: Wood handbookwood as an engineering material. Madison: U.S. Department of Agriculture; 2021.

12. Craig BA, Abdullahi AA. Lumber: Engineered-Strand [Internet]. Amsterdam: Elsevier; 2016 [cited date 2021 April 19]. Available from: https://www.sciencedirect.com/science/article/pii/B9780128035818019883.

13. American Wood Council. Annual production capacity of LSL in North America. Leesburg, VA: American Wood Council; 2020.

14. American Wood Council, Canadian Wood Council. North American laminated strand lumber [Internet]. Leesburg and Ottawa: American Wood Council and Canadian Wood Council; 2021 
[cited date 2021 June 14]. Available from: https://awc.org/docs/default-source/epds/1011 american-wood-council epd north-american-laminated-strandlumber.pdf?sfvrsn=21b306bc 2.

15. Hill CA, Dibdiakova J. The environmental impact of wood compared to other building materials. Int Wood Prod J. 2016 ; 7: 215-219.

16. Werner F, Richter K. Wooden building products in comparative LCA: A literature review. Int J Life Cycle Assess. 2007; 12: 470.

17. Bergman R, Puettmann M, Taylor A, Skog KE. The carbon impacts of wood products. For Prod J. 2014; 64: 220-231.

18. Puettmann ME, Bergman R, Hubbard S, Johnson L, Lippke B, Oneil E, et al. Cradle-to-gate lifecycle inventory of US wood products production: CORRIM Phase I and Phase II products. Wood Fiber Sci. 2010; 42: 15-28.

19. Sahoo K, Bergman R, Alanya-Rosenbaum S, Gu H, Liang S. Life cycle assessment of forest-based products: A review. Sustainability. 2019; 11: 4722.

20. ISO 21930. Sustainability in buildings and civil engineering works - Core rules for environmental product declarations of construction products and services [Internet]. Geneva, Switzerland: ISO; 2017. Available from: https://www.iso.org/standard/61694.html.

21. Bergman R, Taylor A. EPD-Environmental product declarations for wood products-An application of life cycle information about forest products. For Prod J. 2011; 61: 192-201.

22. United States Environmental Protection Agency. About the environmentally preferable purchasing program [Internet]. Washington, DC: United States Environmental Protection Agency; 2021 [cited date 2021 September 24]. Available from: https://www.epa.gov/sustainable-marketplace-greener-products-and-services/aboutenvironmentally-preferable-purchasing.

23. Sandberg D. Additives in wood products-Today and future development. In: Environmental impacts of traditional and innovative forest-based bioproducts. 1st ed. Singapore: Springer; 2016.

24. ISO 14040. Environmental management: Life cycle assessment: Principles and framework [Internet]. Geneva, Switzerland: ISO; $2006 . \quad$ Available from: https://www.iso.org/standard/37456.html.

25. ISO 14044. Environmental management: Life cycle assessments: Requirements and guidelines [Internet]. Geneva, Switzerland: ISO; 2006. Available from: https://www.iso.org/standard/38498.html.

26. UL Environment. Guidance for building-related products and services: Part A: Life cycle assessment calculation rules and report requirements. 5th ed. Washington, DC: UL Environment; 2018.

27. UL Environment. Guidance for building-related products and services: Part B: Structural and architectural wood products EPD requirements. 1st ed. Washington, DC: UL Environment; 2019.

28. Athena Sustainable Materials Institute. A cradle-to-gate life cycle assessment of Canadian oriented strand board-OSB [Internet]. Ottawa: Athena Sustainable Materials Institute; 2018. Available from: http://www.athenasmi.org/wp-content/uploads/2018/09/CtoG-LCA-ofCanadian-OSB.pdf. 
29. Oneil EE, Johnson LR, Lippke BR, McCarter JB, McDill ME, Roth PA, et al. Lifecycle impacts of inland northwest and northeast/north central forest resources. Wood Fiber Sci. 2010; 42: 2951.

30. Tripathi J, Rice RW. Thermal conductivity values for laminated strand lumber and spruce for use in hybrid cross-laminated timber panels. BioResources. 2017; 12: 8827-8837.

31. Denizli-Tankut N, Smith LA, Smith WB, Tankut AN. Physical and mechanical properties of laminated strand lumber treated with fire retardant. For Prod J. 2004; 54: 63-70.

32. CORRIM. Cradle-to-gate life-cycle assessment of North American laminated strand lumber production. Oshkosh, WI: CORRIM, WoodLife Environmental Consultants; 2015.

33. Glass SV, Zelinka SL. Chapter 4: Moisture relations and physical properties of wood. In: Wood handbook-wood as an engineering material [Internet]. Madison: U.S. Department of Agriculture, Forest Service, Forest Products Laboratory; 2021 [cited date 2021 June 17]. Available from: https://www.fs.usda.gov/treesearch/pubs/62243.

34. United States Environmental Protection Agency. TRI chemical list for reporting year 2019 [Internet]. Washington DC: United States Environmental Protection Agency; 2021.

35. Sahoo K, Bergman R, Puettmann M. Cradle-to-gate lifecycle assessment of laminated strand lumber production. Madison, WI: U.S. Department of Agriculture, Forest Service, Forest Products Laboratory; 2021; FPL-RP-710.

36. Pré-Consultants. SimaPro 9 - life cycle assessment software package.

37. The Information Technology Laboratory. Weighted standard deviation. Gaithersburg: The Information Technology Laboratory; 1996. Available from: https://www.itl.nist.gov/div898/software/dataplot/refman2/ch2/weightsd.pdf.

38. Long Trail Sustainability. Datasmart LCl package [Internet]. Huntington: Long Trail Sustainability; 2020. Available from: https://ltsexperts.com/services/software/datasmart-life-cycleinventory/.

39. United States Environmental Protection Agency. Compilation of air pollutant emissions factors, volume 1: Stationary point and area sources [Internet]. Washington DC: United States Environmental Protection Agency; 2021. Available from: https://www.epa.gov/air-emissionsfactors-and-quantification/ap-42-compilation-air-emissions-factors\#5thed.

40. Puettmann ME, Milota M. Life-Cycle assessment for wood-fired boilers used in the wood products industry. For Prod J. 2017; 67: 381-389.

41. AWC. Personal correspondence with experts. 2021.

42. Hart J, D’Amico B, Pomponi F. Whole-Life embodied carbon in multistory buildings: Steel, concrete and timber structures. J Ind Ecol. 2021; 25: 403-418.

43. Gervasio H, Dimova S. Model for life cycle assessment (LCA) of buildings. Brussels: Publications Office of the European Union; 2018; EUR 29123 EN.

44. Winistorfer $P$, Chen Z, Lippke B, Stevens N. Energy consumption and greenhouse gas emissions related to the use, maintenance, and disposal of a residential structure. Wood Fiber Sci. 2005; 37: 128-139.

45. United States Environmental Protection Agency. Documentation chapters for greenhouse gas emission, energy and economic factors used in the waste reduction model (WARM) [Internet]. Washington DC: United States Environmental Protection Agency; 2020. Available from: https://www.epa.gov/warm/documentation-chapters-greenhouse-gas-emission-energy-andeconomic-factors-used-waste-reduction. 
46. Shooshtarian S, Caldera S, Maqsood T, Ryley T. Using recycled construction and demolition waste products: A review of stakeholders' perceptions, decisions, and motivations. Recycling. 2020; 5: 31.

47. Bergman RD, Falk RH, Gu H, Napier TR, Meil J. Life-cycle energy and GHG emissions for new and recovered softwood framing lumber and hardwood flooring considering end-of-life scenarios [Internet]. Madison: U.S. Department of Agriculture, Forest Service, Forest Products Laboratory; 2013 [cited date 2021 October 15]. Available from: https://www.fs.usda.gov/treesearch/pubs/43547.

48. Roussat N, Dujet $C$, Méhu J. Choosing a sustainable demolition waste management strategy using multicriteria decision analysis. Waste Manage. 2009; 29: 12-20.

49. Bare J. TRACI 2.0: The tool for the reduction and assessment of chemical and other environmental impacts 2.0. Clean Techn Environ Policy. 2011; 13: 687-696.

50. Guinée JB. Handbook on life cycle assessment: Operational guide to the ISO standards. Int J Life Cycle Assess. 2002; 7: 311.

51. Frischknecht R, Wyss F, Knöpfel SB, Lützkendorf T, Balouktsi M. Cumulative energy demand in LCA: The energy harvested approach. Int J Life Cycle Assess. 2015; 20: 957-969.

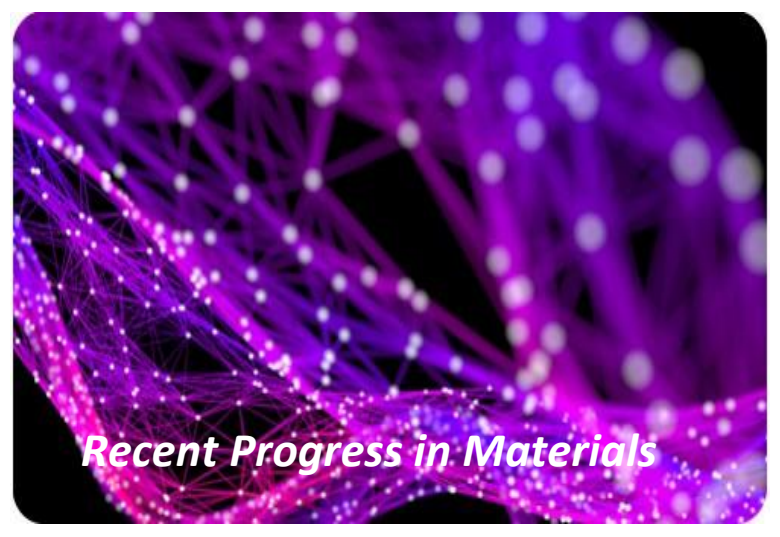

Enjoy Recent Progress in Materials by:

1. Submitting a manuscript

2. Joining in volunteer reviewer bank

3. Joining Editorial Board

4. Guest editing a special issue

For more details, please visit:

http://www.lidsen.com/journals/rpm 